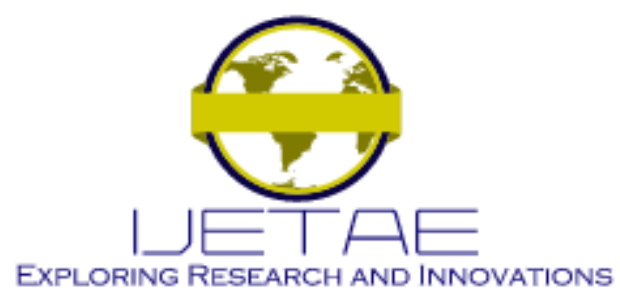

International Journal of Emerging Technology and Advanced Engineering

Website: www.ijetae.com (E-ISSN 2250-2459, Scopus Indexed, ISO 9001:2008 Certified Journal, Volume 11, Issue 07, July 2021)

Manuscript Received: 10 June 2021, Received in Revised form: 10 July 2021, Accepted: 14 July 2021

DOI: $10.46338 /$ ijetae0721_09

\title{
Evaluating the Content Validity of Digital Literacy Instrument for School Teachers in Malaysia through Expert Judgement
}

\author{
Mohammad Fazli Baharuddin ${ }^{1}$, Mohamad Noorman Masrek², Shamila Mohamed Shuhidan ${ }^{3}$, \\ Mohammad Hudzari bin Haji Razali ${ }^{4}$, Mohd Saiful Rahman ${ }^{5}$ \\ ${ }^{1}$ Senior Lecturer, ${ }^{2}$ Professor, ${ }^{3}$ Senior Lecturer, Faculty of Information Management, Universiti Teknologi MARA, Malaysia \\ ${ }^{4}$ Assoc. Professor, Faculty of Agrotechnology and Plantation, Universiti Teknologi MARA (Melaka), Malaysia \\ ${ }^{5}$ Faculty of Information Management, Universiti Teknologi MARA, Malaysia
}

\begin{abstract}
In the development of digital technology, schools must equip students with digital literacy skills to develop thinking both critically and creatively and make teaching and learning relevant to the students. There are various measuring instruments that have been developed to assess digital literacy for various target groups. However, quality and valid instruments are still limited and lacking. It is important to apply a valid measuring instrument for digital literacy based on its results in the case of overlapping and ambiguous constructions in the name of digital literacy. Thus, to assess the content validity of the questionnaire that had been generated to evaluate digital literacy of the school teachers is the main focus. The validity of the content was used as a criterion to confirm that the questionnaire was of high quality. The instrument's content validity was assessed according to the feedbacks of six professional in the field. The item content validity index and scale content validity index were implemented for content validity. Three (3) constructs namely; technical, cognitive, and social-emotional contain 6 items each were identified. The results of content validity index (I-CVI) showed between 0.97 to 1 and the scale content validity index (S-CVI/Ave) for the technical, cognitive, and social-emotional dimension of digital literacy was $1.00,0.97$, and 0.97 respectively. The questionnaire was identified with acceptable content validity. Further research able to guarantee that the questionnaire is checked for reliability as well as the other types of validity, including as face validity, construct validity, and criterion validity, in order to improve the assessment instrument's usefulness.
\end{abstract}

Keywords - Instrument Assessment, Scale Content Validity Index, Content Validity Index, Digital Literacy, School Teachers.

\section{INTRODUCTION}

Malaysia in its efforts to develop a system of education that is on par with the best in the world that able to generate innovative and high-quality human capital.
However, the current reality shows output growth very slow. Malaysia's innovative and creativity still lacking as shown in the total output and education components' contributions to production progress that are both stagnant [1]. This shows that Malaysia's efforts to innovate are still lacking. In previous studies have explained one of the reasons a country is less innovative is because the education system in the country does not produce innovative skills needed by industry and organizations [2]. Therefore, someone who is innovative is much needed in the education discipline, especially teachers who are innovative in diversifying approaches of teaching and learning [3]. Teachers are also expected to change according to the current situation and ensure that the needs and requirements of the industry are met and instilling innovative values among the students [4].

Innovative teaching also been suggested to be emphasized whereby the varied teaching and learning approaches and content would help students. This is because students come from various backgrounds such as religion, culture, Education level, school where they study and the learning facilities provided [5]. Due to this diversity, teaching methods should also vary according to the suitability of the students. This is the challenge for teachers today to ensure that teaching needs are met. To ensure that every need is met, innovative teaching should be implemented by teachers, and various teaching strategies should be developed by teachers in the classroom [6].

In addition, some previous literature is the same mind whereby one of the teachers' competencies that could support innovative and creativity in teaching and learning process is digital literacy skills [7] [8]. Whereby Martin and Grudziecki [9] assume digital literacy as a requirement for entrepreneurship, creativity, and innovation. 


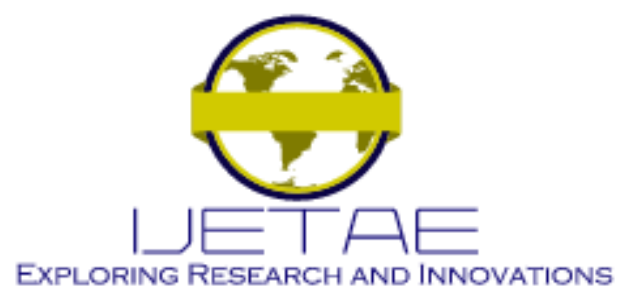

International Journal of Emerging Technology and Advanced Engineering

Website: www.ijetae.com (E-ISSN 2250-2459, Scopus Indexed, ISO 9001:2008 Certified Journal, Volume 11, Issue 07, July 2021)

It agreed by Hague and Payton [10] which is digital literacy can help with whole-school initiatives as well as subject knowledge growth in individual teachers' classrooms. A commitment to digital literacy as a wholeschool approach can enable schools to support students in taking advantage of the opportunities provided by digital technologies, to develop critical thinking and creativity in young people, and to engage with their lives in a way that has the potential to make their learning more relevant. In this regard, digital literacy is considered and capable to alter the strength of any determinants that drive innovative work behaviour. Therefore, in studying digital literacy, it is vital to apply valid research questionnaire to avoid construct overlapping. Thus, this research is to assess the validity of the items of research instruments developed to assess digital literacy among school teachers in Malaysia.

\section{LITERATURE REVIEW}

The term 'digital literacy' was first used by Gilster [11] in the late $1990 \mathrm{~s}$, and its use is very close to the field of education which is fundamental to the existence of the Internet. It is to identify the ability of students in making them digital literate and have set of information skills such as searching and evaluating accurate information based on available resources such as text and multimedia that exist on the Internet that can help their learning the school. Noh [12] provides a clearer view of the position of digital literacy in an umbrella of skills, which is basically a skill of using digital information including the ability to identify, access and use in various formats including text, sound and images. It supported by Meyers et al., [13], which definition of this term looks not only at the use of technology but it is also a collaboration with information literacy skills which search, extract, compile, manage, present and evaluate information, but in the context of a digital environment. It is also a complex conceptual framework and encompasses a wide range of other information-related skills such as understandings, norms and practices.

The Ministry of Education Malaysia launched the Malaysian Smart School which is known as the "Sekolah Bestari" in 1999. It is a systematic learning institute developed to innovate teaching and learning where management of school prepares students for the Information Era and promoting National Philosophy of Education's goals and vision.
This is the 7th change in the recent Malaysian Education Development Plan (2013-2025), in which the Ministry stated its intention to use ICT as an approach to enhance the value of learning throughout the education system in Malaysia [14]. "1Bestarinet" developed by the Ministry of Education should be used as a virtual learning platform in schools by teachers. Nevertheless, its usage in teaching and learning is still low in most schools in the country [15].

Numerous researches and publications discuss the changes in the education system and most of it discussed about the 21st century learning [16] [17] [15] [10] [18]. The literature of the 21 st century learning, many had focus on the change in terms of teaching methods in the classroom, one of which is about digital learning. Teachers are no longer just emphasize on basic literacy such as reading, calculating and writing, but with today's sophistication of technology, the focus is more on creation, sharing, socializing, research, collaborate, communicate in learning [13]. Due to that demand, teachers need to emphasis and incorporate digital literacy to students in each in their lessons. According to Ng [19] suggested, three (3) dimensions for digital literacy are technical, cognitive and social-emotional as follow:

\section{a) Technical}

Teachers' ability to possess the technical aspects and operational skills in order to use digital tools for teaching and in their daily tasks such as uploading, downloading and installing applications.

\section{b) Cognitive}

Teachers' ability to search, evaluate, select and use appropriate digital information to do a specific task related teaching and learning.

\section{c) Social-Emotional}

Teachers' ability to use the digital tools responsibly in communicating, socializing and learning.

In Malaysia, many schools have started focused on digital literacy which equip as one of the teacher's skills. According to Samsudin [20] as a teacher librarian in MARA Science Junior College (MRSM) Felda Trolak, Perak, digital literacy has begun to be stressed as compulsory for teachers because it is contained in the teaching plan. It is also a direction from MARA's top management. Therefore, various programs involving digital literacy have been implemented. 


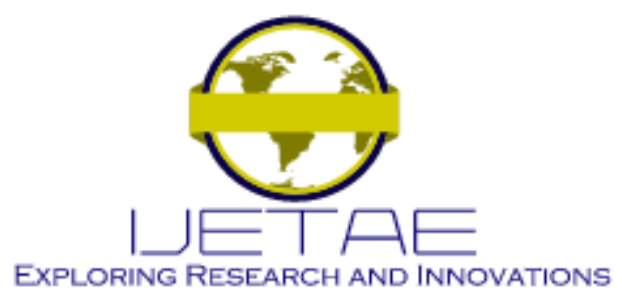

\section{International Journal of Emerging Technology and Advanced Engineering Website: www.jjetae.com (E-ISSN 2250-2459, Scopus Indexed, ISO 9001:2008 Certified Journal, Volume 11, Issue 07, July 2021)}

Among the programs that have been implemented is the Digital Classroom Workshop presented by the National Education Technology Icon of 2017. One of the objectives is to prepare teachers for more creative and effective in delivering knowledge in the classroom through the process of teaching and learning. In addition, they assume, to produce innovative students, the teachers must first be creative and innovative and start from within the classroom.

Human behaviour moderated by our effectiveness and self-efficacy beliefs, and at the same time influence our decisions, effort, and tenacity when faced with adversity, as well as our emotions, referring to social cognitive theory [21] [22]. Self-efficacy can be described as an individual's conviction in their ability to achieve certain levels of performance that have an impact on events in their lives [23]. Meanwhile, self-efficacy of teacher relates to a teacher's conviction in his or her own competence to organise, coordinate, and carry out the actions required to meet specified educational objectives, whereas perceived collectively, teacher's self-efficacy refers to a teacher's confidence in teamwork and his or her school in planning, managing and implementing certain activities to achieve a goal [24]. Bandura [23] has explained that individuals with high self-efficacy will believe that they are able to give well performance and provide high commitment in the face of all obstacles that will be encountered while performing a task. Predictions of teacher goals and teacher attitudes point towards innovation and change through high self-efficacy. [21]. It seems very clear when a person with strong selfefficacy will be extra courageous to participate in challenging tasks which involve creative practice [25].

According to Prior, Mazanov, Meacheam, Heaslip, and Hanson [26] raised that strong self-efficacy often indicates better confidence and having autonomy in performing tasks. This is because the nature of high self-efficacy has been connected with high motivation and at the same time form the nature of self-reliance in the individual [27]. This is coupled with the development of ICT which is a factor in the change at different education levels, for instance, in terms of access to ICT tools in schools, internet connectivity, and the move from paper-based to computerbased assessments [28]. According to Siddiq and Scherer [29], one among the most significant antecedents for teachers integrate ICT in their teaching and learning proces is teachers' computer self-efficacy (CSE). In a current study, Borthwick and Hansen [30] showed that teachers' self-efficacy in using digital tools for the purposes of instructional and digital literacy were positive relationship.
Prior, Mazanov, Meacheam, Heaslip, and Hanson [26] study focusing on roles of digital literacy in achieving selfefficacy among employees as well.

Thus, digital literacy can be interpreted as a person's willingness, behaviour and ability to apply all digital elements, tools and facilities effectively in identifying, accessing, managing, integrating, evaluating and synthesizing digital resources, developing new wisdom and theories, sharing in digital platforms as well as being able to communicate virtually well, in a variety of situations and environments, to enable social activities and produce appropriate responses [26]. Prior, Mazanov, Meacheam, Heaslip, and Hanson [26] also recommends that digital literacy has equipped with four main characteristics. First, digital literacy is a must-have ability for everyone and is indispensable for every aspect of life today. Second, however, digital literacy also differs according to individual life circumstances such as socio-economic differences. Third, digital literacy is not limited to ICT literacy only as it is also related to individual skills in other aspects. Fourth, digital literacy entails the acquisition and use of knowledge, skills, attitudes, and personal characteristics.

Furthermore, digital literacy encompasses the capability to plan, accomplish, and assess digital activities in the context of completing real activities, as well as the competence to react on any activities. Basically, digital literacy encompasses the ability of individuals to recognize and construe information appropriately through the application of ICT in a way that assist achieving their own aims [8]. Thus, digital literacy is seen to be very important in most cases where it is considered to support course design regardless of the mode of instruction by the teacher. The best way is to embed digital literacy in various courses that involve searching for information on the internet, library websites and databases, as well as how to communicate through digital technology [30] [31].

In addition, digital literacy can be moderated as crucial competency for school teachers in order to encourage innovative work behaviour in education organization [8]. Therefore, if digital literacy skills are improved, it will help to strengthen any determinants of teachers towards innovative work behaviour and support the concept of autonomy and commitment. In contrast, Hsiao et al. [21] found that teachers having self-efficacy is not only necessary will apply innovative work behaviour. Therefore, encouragement to improve teachers' digital literacy skills needs to be the main focus and implemented quickly. 


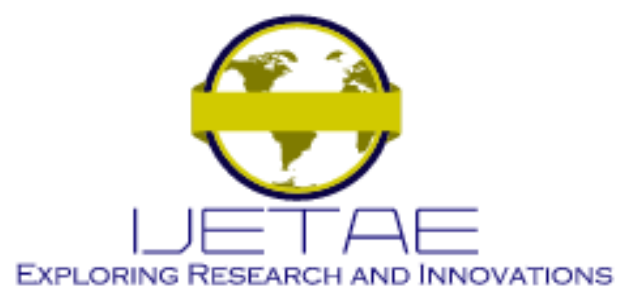

\section{International Journal of Emerging Technology and Advanced Engineering}

Website: www.ijetae.com (E-ISSN 2250-2459, Scopus Indexed, ISO 9001:2008 Certified Journal, Volume 11, Issue 07, July 2021)

Various courses and workshops need to be established to ensure that teachers can successfully encounter the challenges of today's teaching. At the same time this will help shape innovative work behaviour among teachers [32].

\section{METHODOLOGY}

\section{A. Instrument Development}

Questionnaire design is a significant and can describe the contrast between a high response rate that offers extensive data and a low response rate that offers no data which insufficient to answer the research question [33]. Incomplete questionnaire design and not going through the validation process will make respondents not interested in participating in this survey and will create measurement errors. measurement error [34]. Thus, in order to identify dimensions that can be used for research on digital literacy, a comprehensive review of previous literature has been conducted. A review of previous studies was conducted to help researchers identify research gaps that exist between constructs [35]. With the existence of numerous previous studies, there are often inconsistencies, especially on the definition of digital literacy which is seen as less accurate on the concept. There was a substantial divide among academician and industrial perspectives on digital literacy [25]. To fill this research gap, the development of constructs involving the opinions of both academia and practitioners in the industry should be taken into account. In order to find out the information and items required; a preliminary study has been conducted as a prerequisite to validate the initial questionnaire prepared based on previous studies. This is important because the research setting may vary from the current study. Six teachers were identified and invited for this purpose. To ensure that the participation of these teachers was in accordance with the study's objectives, a set of criteria was determined by which these teachers taught in secondary and boarding schools. The teachers teach different subjects such as Malay Language, Geography, Physics, English, Chemistry and Mathematics.

A different date is selected after obtaining approval to implement this preliminary study. Open-ended questions were asked during the interviews which derived from a review of previous literatures and coincided with the work atmosphere of teachers in their workplace which is school. The open-ended questions may produce important thoughts, to ensure teachers understand every question that researcher asks and achieve the objectives of the study [36].
Not only into respondents' substantive answers. Researchers also try to ensure that respondents understand the questions asked by using layman language and try to avoid using jargon words that may confuse respondents. Because if the respondent is confused with the question, the answer obtained may be inaccurate and confusing. Therefore, the experience as a former teacher is very helpful to the researcher in the interview because it understands the teacher's work environment. Six items for each dimension of digital literacy are listed in Table I. All of the questions were derived from the previous literature with a combination of feedbacks from conducted preliminary study. Questions developed particularly for this research which were improved and adopted from original questionnaire developed by previous studies in different research setting [19] [30] [12] [37] [38] [39] [40] [31]. To meet the objectives of this study, some amendments and improvements have been made by researchers on these items which are related to the total of questions, the wording, sentences, and scale for questions to ensure appropriate on the work environment of teachers in Malaysia and the education system used.

TABLE I

ITEMS FOR EACH DIMENSION

\section{Technical}

1 I use digital technology and devices to support my teaching and learning

2 I am competent in using application software such as email, search engine, web browser

3 I know how to solve technical problems related to my digital technology tools

4 I keep up date with new digital tools and application use in teaching and learning

5 I am familiar with the process of uploading, downloading and installing applications

6 I can perform file management including deleting and renaming files, etc.

\section{Cognitive}

1 I am familiar with the online resources such as websites and online databases

2 I browse, search and filter the information and digital content from websites and online databases

3 I know when to change my search strategy or stop searching when using websites and online databases

4 I evaluate whether digital information is credible and trustworthy before use it

5 I can integrate information that comes from different online sources

6 I keep a record on relevant details of digital information that are found online 


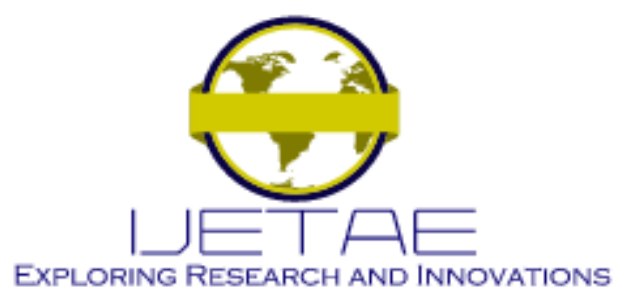

International Journal of Emerging Technology and Advanced Engineering Website: www.ijetae.com (E-ISSN 2250-2459, Scopus Indexed, ISO 9001:2008 Certified Journal, Volume 11, Issue 07, July 2021)

\begin{tabular}{ll}
\hline Social-Emotional \\
\hline 1 & $\begin{array}{l}\text { I acknowledge who owns information and ideas that I find } \\
\text { online }\end{array}$ \\
\hline 2 & I avoid plagiarism \\
\hline 3 & $\begin{array}{l}\text { I share files such as documents, video and audio legally with } \\
\text { others }\end{array}$ \\
\hline 4 & $\begin{array}{l}\text { I communicate with others via online such as forums, social } \\
\text { networking, blogs, etc. }\end{array}$ \\
\hline 5 & I comment on social media, blogs, forums or websites \\
\hline 6 & $\begin{array}{l}\text { I observe etiquette and appropriate social conventions for } \\
\text { online communication }\end{array}$ \\
\hline
\end{tabular}

\section{B. Pre-testing}

Once the instrument has been developed, a content validation process needs to be done to evaluate the instrument. Therefore, six experts were invited to evaluate this instrument. This process is called pre-testing. Pretesting the instrument is a critical step in identifying issue areas, reducing measurement error, reducing respondent confusion, determining whether respondents accurately understanding questions, and ensuring that the arrangement of questions does not influence how a respondent feedback [41] [42]. Although it is almost unattainable to develop a flawless instrument, but many things need to be taken into account and given attention in developing a good instrument [43]. Therefore, several requirements must be taken into consideration in selecting an expert to verify the validity of the content for the instrument, namely in terms of the expertise of the expert's knowledge, qualifications and professional experience in this field of study. Three categories of validity in pre-testing the instrument, namely; content validity, criterion-related validity and construct validity [44]. Content validity was selected in measuring quality of questionnaire in this study. Content validity refers as the level to which a questionnaire has a proper sample of items for the dimension being evaluated [45]. Content validity seems should be given priority in illustrating the conclusions about the scale's quality Meanwhile the criterion-related and construct validity of the instrument also can be considered. According to Cooper [42], pre-test may be implemented through face-to-face, mailed questionnaire, telephone interview and also via email. However, face-to-face is the best method for pretesting since the researcher can observe the reactions and attitudes of respondents for every item in the questionnaire. Thus, in this study, the pre-test was implemented through face-to-face to review the instruments.
A minimum of three experts is very appropriate according to Lynn [46], however more than 10 experts is not necessary. In this study, six experts were asked to perform an evaluation on the instrument. They are two experts in the field of research and are Associate Professors from Public Universities in the Klang Valley. They are also very knowledgeable and competent in the education field, digital literacy and research methodologies in the field of Social Sciences. The others are three prospective respondents. This pre-testing was also done by education officers from the Sektor Pengurusan Sekolah, State Education Division. Table II showcase the information of experts involved in this research and contributed their responses.

TABLE II

PANEL EXPERTS

\begin{tabular}{|c|l|c|}
\hline No & \multicolumn{1}{|c|}{ Panel Experts } & Organization \\
\hline 1 & Associate Professor & University A \\
\hline 2 & Associate Professor & University B \\
\hline 3 & Teacher (DG44) & School A \\
\hline 4 & Teacher (DG41) & School B \\
\hline 5 & Teacher (DG44) & State Education Division \\
\hline 6 & $\begin{array}{l}\text { Education Officer } \\
(\text { DG44) }\end{array}$ & \\
\hline
\end{tabular}

\section{FINDINGS}

Two types of Content Validity Index (CVI) suggested in implement content validity [46]. The first CVI is the individual item of content validity and the second CVI is the overall item of content validity. Lynn [46] and Waltz [47] also describe that the use of a 4-point scale is encouraged. However, a 3-point or 5-point scale can also be used. However, Lynn [46] suggested the use of a 4-point scale to evade neutral opinions and midpoint. In this study, four points can be described as: $1=$ No relevance at all, $2=$ Item need some revision, 3 = Relevant but need minor revision, and $4=$ Very relevant. Then, for each item, the content validity index for items (I-CVI) is computed as the number of experts giving a rating of either 3 or 4 (thus dichotomizing the ordinal scale into relevant and not relevant), divided by the total number of experts. 


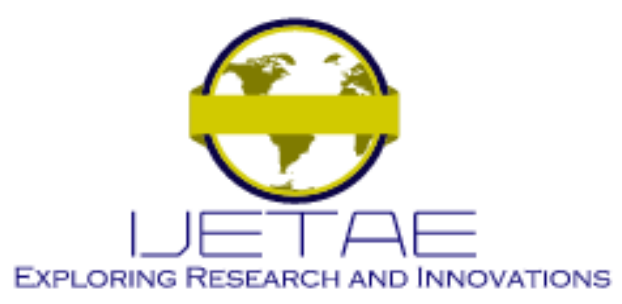

International Journal of Emerging Technology and Advanced Engineering

Website: www.ijetae.com (E-ISSN 2250-2459, Scopus Indexed, ISO 9001:2008 Certified Journal, Volume 11, Issue 07, July 2021)

In this study, minimum I-CVI is 0.83 for 6 experts suggested by Lynn [46]. The other type of content validity performed was content validity index for scales (S- CVI) to measure the content validity of the overall scale which includes Universal Agreement (UA) and Ave (Average). In this study, and Scale Content Validity Index/Average Proportion (S-CVI/AVE) is 0.90 for 6 experts suggested by Lynn [46].

TABLE III

I-CVI AND S-CVI/AVE FOR TECHNICAL (T)

\begin{tabular}{|r|c|c|c|c|c|c|c|c|}
\hline Item & $\begin{array}{c}\text { Ex } \\
\text { pert } \\
1\end{array}$ & $\begin{array}{c}\text { Ex } \\
\text { pert } \\
2\end{array}$ & $\begin{array}{c}\text { Ex } \\
\text { pert } \\
3\end{array}$ & $\begin{array}{c}\text { Ex } \\
\text { pert } \\
4\end{array}$ & $\begin{array}{c}\text { Ex } \\
\text { pert } \\
5\end{array}$ & $\begin{array}{c}\text { Ex } \\
\text { pert } \\
6\end{array}$ & $\begin{array}{c}\text { Number } \\
\text { of } \\
\text { Agreeme } \\
\text { nt }\end{array}$ & $\begin{array}{c}\text { Ite } \\
\mathrm{m} \\
\text { CVI }\end{array}$ \\
\hline $\mathrm{T} 1$ & 1 & 1 & 1 & 1 & 1 & 1 & 6 & 1.00 \\
\hline $\mathrm{T} 2$ & 1 & 1 & 1 & 1 & 1 & 1 & 6 & 1.00 \\
\hline $\mathrm{T} 3$ & 1 & 1 & 1 & 1 & 1 & 1 & 6 & 1.00 \\
\hline $\mathrm{T} 4$ & 1 & 1 & 1 & 1 & 1 & 1 & 6 & 1.00 \\
\hline $\mathrm{T} 5$ & 1 & 1 & 1 & 1 & 1 & 1 & 6 & 1.00 \\
\hline $\mathrm{T} 6$ & 1 & 1 & 1 & 1 & 1 & 1 & 6 & 1.00 \\
\hline Proportio & 1.0 & 1.0 & 1.0 & 1.0 & 1.0 & 1.0 & $\begin{array}{l}\text { Mean I- } \\
\text { CVI: }\end{array}$ & 1.00 \\
Relevant: & 0 & 0 & 0 & 0 & 0 & 0 & \\
\hline & & & & & & & $\begin{array}{l}\text { S- } \\
\text { CVI/UA: }\end{array}$ & 1.00 \\
\hline & & & & & & & $\begin{array}{l}\text { S- } \\
\text { CVI/AVE } \\
:\end{array}$ & 1.00 \\
& & & & & & & & \\
\hline
\end{tabular}

TABLE IV

I-CVI AND S-CVI/AVE FOR COGNITIVE (C)

\begin{tabular}{|r|c|c|c|c|c|c|c|c|}
\hline Item & $\begin{array}{c}\text { Ex } \\
\text { pert } \\
1\end{array}$ & $\begin{array}{c}\text { Ex } \\
\text { pert } \\
2\end{array}$ & $\begin{array}{c}\text { Ex } \\
\text { pert } \\
3\end{array}$ & $\begin{array}{c}\text { Ex } \\
\text { pert } \\
4\end{array}$ & $\begin{array}{c}\text { Ex } \\
\text { pert } \\
5\end{array}$ & $\begin{array}{c}\text { Ex } \\
\text { pert } \\
6\end{array}$ & $\begin{array}{c}\text { Number } \\
\text { of } \\
\text { Agreeme } \\
\text { nt }\end{array}$ & $\begin{array}{c}\text { Ite } \\
\mathrm{m} \\
\text { CVI }\end{array}$ \\
\hline $\mathrm{C} 1$ & 1 & 1 & 1 & 1 & 1 & 1 & 6 & 1.00 \\
\hline $\mathrm{C} 2$ & 1 & 1 & 1 & 1 & 1 & 1 & 6 & 1.00 \\
\hline $\mathrm{C} 3$ & 1 & 1 & 1 & 1 & 1 & 1 & 6 & 1.00 \\
\hline $\mathrm{C} 4$ & 1 & 1 & 1 & 1 & 1 & 1 & 6 & 1.00 \\
\hline $\mathrm{C} 5$ & 1 & 1 & 1 & 1 & 1 & 1 & 6 & 1.00 \\
\hline $\mathrm{C} 6$ & 1 & 0 & 1 & 1 & 1 & 1 & 5 & 0.83 \\
\hline Proportio & 1.0 & 0.8 & 1.0 & 1.0 & 1.0 & 1.0 & $\begin{array}{l}\text { Mean I- } \\
\text { CVI: }\end{array}$ & 0.97 \\
Relevant: & 0 & 3 & 0 & 0 & 0 & 0 & \\
\hline & & & & & & & $\begin{array}{l}\text { S- } \\
\text { CVI/UA: }\end{array}$ & 0.83 \\
\hline & & & & & & & $\begin{array}{l}\text { S- } \\
\text { CVI/AVE } \\
:\end{array}$ & 0.97 \\
\hline
\end{tabular}

TABLE V

I-CVI AND S-CVI/AVE FOR SOCIAL EMOTIONAL (SE)

\begin{tabular}{|r|c|c|c|c|c|c|c|c|}
\hline Item & $\begin{array}{c}\text { Ex } \\
\text { pert } \\
1\end{array}$ & $\begin{array}{c}\text { Ex } \\
\text { pert } \\
2\end{array}$ & $\begin{array}{c}\text { Ex } \\
\text { pert } \\
3\end{array}$ & $\begin{array}{c}\text { Ex } \\
\text { pert } \\
4\end{array}$ & $\begin{array}{c}\text { Ex } \\
\text { pert } \\
5\end{array}$ & $\begin{array}{c}\text { Ex } \\
\text { pert } \\
6\end{array}$ & $\begin{array}{c}\text { Number } \\
\text { of } \\
\text { Agreeme } \\
\text { nt }\end{array}$ & $\begin{array}{c}\text { Ite } \\
\mathrm{m} \\
\text { CVI }\end{array}$ \\
\hline SE1 & 1 & 1 & 1 & 1 & 1 & 1 & 6 & 1.00 \\
\hline SE2 & 1 & 1 & 1 & 1 & 1 & 1 & 6 & 1.00 \\
\hline SE3 & 1 & 1 & 1 & 1 & 1 & 1 & 6 & 1.00 \\
\hline SE4 & 1 & 1 & 1 & 1 & 1 & 1 & 6 & 1.00 \\
\hline SE5 & 0 & 1 & 1 & 1 & 1 & 1 & 5 & 0.83 \\
\hline SE6 & 1 & 1 & 1 & 1 & 1 & 1 & 6 & 1.00 \\
\hline $\begin{array}{r}\text { Proportio } \\
\text { n }\end{array}$ & 0.8 & 1.0 & 1.0 & 1.0 & 1.0 & 1.0 & $\begin{array}{r}\text { Mean I- } \\
\text { CVI: }\end{array}$ & 0.97 \\
Relevant: & & 0 & 0 & 0 & 0 & S- & 0.83 \\
\hline & & & & & & & CVI/UA: & \\
\hline & & & & & & & S- & 0.97 \\
& & & & & & & CVI/AVE & \\
\hline
\end{tabular}

TABLE VI

SUMMARY OF CONTENT VALIDITY

\begin{tabular}{|c|c|c|c|}
\hline Construct & $\begin{array}{c}\text { No. of } \\
\text { Items }\end{array}$ & $\begin{array}{c}\text { I-CVI } \\
(>= \\
\mathbf{0 . 8 3})\end{array}$ & $\begin{array}{c}\text { S-CVI/Ave } \\
(>=\mathbf{0 . 9 0})\end{array}$ \\
\hline Technical (T) & 6 & 1.00 & 1.00 \\
\hline Cognitive (C) & 6 & 0.97 & 0.97 \\
\hline $\begin{array}{c}\text { Social-Emotional } \\
\text { (SE) }\end{array}$ & 6 & 0.97 & 0.97 \\
\hline
\end{tabular}

The results as shown in Table III until Table $\mathrm{V}$ and had been summarized using Table VI. The I-CVI for all the items of the three constructs ranged from 0.97 to 1.00 . The S-CVI (Average) for technical, cognitive and socialemotional dimension of digital literacy were 1.00 (Table 3), 0.97 (Table 4), and 0.97 (Table 5) respectively. The overall S-CVI for the 18 -item scale was 0.98 which indicated high content validity of the items for the construct of digital literacy. Completely of the constructs are remained because they have a high level of consensus among experts. It can be concluded that the pre-testing results are exceed the suggested threshold, and the study constructs chosen are valid.

\section{CONCLUSION}

The study is to identify the constructs used for assessing digital literacy in the context for boarding school teachers for a developing country such as Malaysia. 


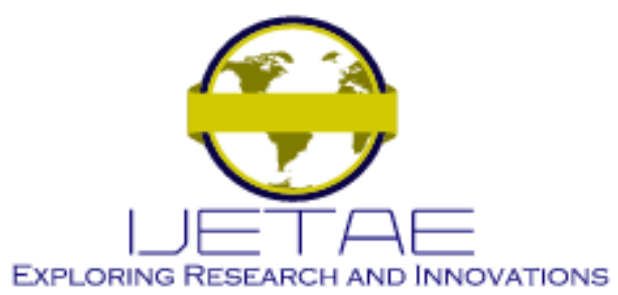

\section{International Journal of Emerging Technology and Advanced Engineering Website: www.ijetae.com (E-ISSN 2250-2459, Scopus Indexed, ISO 9001:2008 Certified Journal, Volume 11, Issue 07, July 2021)}

The literature review exercise had identified the appropriate dimensions and the corresponding. However, given that these dimensions were originally developed for non-boarding school teachers, further validation was conducted and the results showed that these dimensions, namely, technical, cognitive and social-emotional were found to be relevant. In addition, the corresponding scales were also revised and the validation exercise showed that validity scores were highly reliable. Hence, researcher intending to examine digital literacy of boarding school teachers may consider adopting this scale. While the study has successfully achieved its objective, it also suffers several limitations. The first and foremost is the dimensions chosen were purely based on a study done in the Malaysian context. Every country has its own schooling systems and due to that, care should be taken when adopting these dimensions and scales. Secondly, the chosen dimensions are also too narrow in terms of its scope, hence future research should consider extending by integrating other themes or category as highlighted in the literature review section.

\section{Acknowledgement}

The researcher would like extend our thanks to all respondents who participated in this study and also Universiti Teknologi MARA (UiTM) for providing all the necessary supports throughout the conduct of the study. The study is registered in UiTM as 600-IRMI/FRGS 5/3 (459/2019).

\section{REFERENCES}

[1] National Economic Advisory Council. 2010 New Economic Model for Malaysia.

[2] Serdyukov, P. 2017 "Innovation in education: what works, what doesn't, and what to do about it?," Journal of Research in Innovative Teaching \& Learning, vol. 10, no. 1, pp. 4-33, https://doi.org/10.1108/JRIT-10-2016-0007

[3] Thurlings, M., Evers, A. T., and Vermeulen, M. 2015 "Toward a Model of Explaining Teachers' Innovative Behavior: A Literature Review," Review of Educational Research, vol. 85, no. 3, https://doi.org/10.3102/0034654314557949

[4] Othman, N. 2016 "Exploring the Innovative Personality Characteristics among Teachers," International Education Studies, vol. 9, no. 4, pp. 1-8, https://doi.org/10.5539/ies.v9n4p1

[5] Naz, F. and Murad, H. S. 2017 "Innovative Teaching Has a Positive Impact on the Performance of Diverse Students," SAGE Open, https://doi.org/10.1177/2158244017734022

[6] Lunde, J. P., Wilhite, M. S. and Wilhite M. S., 1996 "Innovative Teaching and Teaching Improvement," To Improve the Academy, vol. 15 .
[7] Mohammadyari, S. and Singh, H. 2015 "Understanding the effect of e-learning on individual performance: The role of digital literacy," Computers \& Education, vol. 82, pp. 11-25, https://doi.org/10.1016/j.compedu.2014.10.025

[8] Tang, C. M. and Chaw, L. Y. 2016 "Digital Literacy: A Prerequisite for Effective Learning in a Blended Learning Environment?" Electronic Journal of E-Learning, vol. 14, no. 1, pp. 54-65.

[9] Martin, A. and Grudziecki, J. 2006 "DigEuLit: Concepts and Tools for Digital Literacy Development," Innovation in Teaching and Learning in Information and Computer Sciences, vol. 5, no. 4, pp. 249-267, https://doi.org/10.11120/ital.2006.05040249

[10] Hague, C. and Payton, S. 2010 "Digital literacy across the curriculum: a Futurelab handbook," Futurelab, vol. 63, Retrieved from http://www.futurelab.org.uk/ projects/digital-participation

[11] Gilster, P. 1997 "Digital literacy," New York, United States: John Wiley \& Sons, Inc.

[12] Noh, Y. 2017 "A study on the effect of digital literacy on information use behavior," Journal of Librarianship and Information Science, vol. 49, no. 1, pp. 26-56, https://doi.org/10.1177/0961000615624527

[13] Meyers, E. M., Erickson, I. and Small, R. V. 2013 "Digital literacy and informal learning environments: An introduction," Learning, Media and Technology, vol. 38, no. 4, pp. 355-367, https://doi.org/10.1080/17439884.2013.783597

[14] Ministry of Education Malaysia, 2013 "Malaysia Education Blueprint $2013-2025$," Education vol. 27, https://doi.org/10.1016/j.tate.2010.08.007

[15] Ghavifekr, S., Kunjappan, T., Ramasamy, L. and Anthony, A. 2016 "Teaching and Learning with ICT Tools: Issues and Challenges from Teachers' Perceptions," Malaysian Online Journal of Educational Technology, vol. 4, no. 2, pp. 38-57, Retrieved from http://bit.ly/2fRI88H

[16] Climate, C. 2016 "The Mediating Role of Psychological Empowerment on the Relationship between Creative Climate and Innovative Work Behavior: The Case of Employees of Various Sectors in Turkey," Journal of Behavior at Work, vol. 1, no. 1, pp. 74-84

[17] Ghani, A. Abdullah, K. and Ling, Y. 2016 "Understanding Workplace Happiness in Schools: The Relationships Between Workplace Happiness, Teachers' Sense of Efficacy, Affective Commitment and Innovative Behavior," Academy of Social Science Journal, vol. 1, no. 4, pp. 80-83.

[18] Tyger, R. L. 2011 “Teacher Candidates' Digital Literacy and Their Technology Integration Efficacy".

[19] Ng, W. 2012 "Can we teach digital natives digital literacy?" Computers \& Education, vol. 59, no. 3, pp. 1065-1078 https://doi.org/10.1016/j.compedu.2012.04.016

[20] Samsudin, S. 2018 Personal Interview.

[21] Hsiao, H., Chang, J., Tu, Y. and Chen, S. 2011 "The Impact of Selfefficacy on Innovative Work Behavior for Teachers," International Journal of Social Science and Humanity, vol. 1, no. 1, pp. 31-36.

[22] Robin, K. H. 2001 "Teacher Self-efficacy: Substantive Implications and Measurement Dilemmas,". 


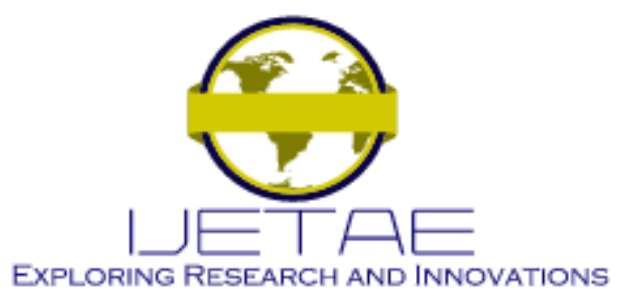

\section{International Journal of Emerging Technology and Advanced Engineering} Website: www.ijetae.com (E-ISSN 2250-2459, Scopus Indexed, ISO 9001:2008 Certified Journal, Volume 11, Issue 07, July 2021)

[23] Bandura, A. 1994 "Self-efficacy," In Encyclopedia of human behavior, New York, United States: Academic Press.

[24] Parthasarathy, J. and Premalatha, T. 2017 "Impact of CollectiveEfficacy and Self-Efficacy on the Innovative Work Behaviour of Teachers in the Nilgiris District, Tamil Nadu," The International Journal of Indian Psychology, vol. 5, no. 1 . https://doi.org/10.25215/0501.019

[25] Dörner, N. 2012 "Innovative Work Behavior: The Roles of Employee Expectations and Effects on Job Performance,".

[26] Prior, D. D., Mazanov, J., Meacheam, D., Heaslip, G. and Hanson, J. 2016 "Attitude, digital literacy and self-efficacy: Flow-on effects for online learning behavior," Internet and Higher Education, vol. 29, pp. 91-97 https://doi.org/10.1016/j.iheduc.2016.01.001

[27] Runhaar, P. R., Sanders, K. and Yang, H. 2013 "Promoting Teachers' Innovative Behaviour: The roles of interdependence, Occupational Self-Efficacy and Learning Goal Orientation," In Annual Meeting 2013 of the American Educational Research Association, pp. 1-13.

[28] Andema, S. 2014 "Promoting Digital Literacy in African Education: ICT Innovations in a Ugandan Primary Teachers' College,".

[29] Siddiq, F. and Scherer, R. 2016 "The relation between teachers' emphasis on the development of students' digital information and communication skills and computer self-efficacy: the moderating roles of age and gender," Large-Scale Assessments in Education, vol. 4, no. 1, vol. 17. https://doi.org/10.1186/s40536-016-0032-4

[30] Borthwick, A. C. and Hansen, R. 2017 "Digital Literacy in Teacher Education: Are Teacher Educators Competent?" Journal of Digital Learning in Teacher Education, vol. 33, no. 2, pp. 46-48, https://doi.org/10.1080/21532974.2017.1291249

[31] Hague, C. and Williamson, B. 2009 "Digital Participation, Digital Literacy, and School Subjects: A Review of the Policies, Literature and Evidence,".

[32] Ko, K. D., Brand-gruwel, S. and Van. Merrie, J. J. G. 2006 "Teachers' perspectives on innovations: Implications for educational design," Teaching and Teacher Education, https://doi.org/10.1016/j.tate.2006.06.004

[33] Pickard, A. J. 2013 "Research Methods in Information," (2nd ed.). Chicago: Neal-Schuman.

[34] Thien, L. M., Razak, N. A. and Ramayah, T. 2014 "Validating Teacher Commitment Scale Using a Malaysian Sample," SAGE Open, pp. 1-9, https://doi.org/10.1177/2158244014536744
[35] Musannip, Z., Siregar, E., Ahman, E. and Senen, S. H. 2019 "Factors Influencing Innovative Work Behavior: An Individual Factors Perspective," International Journal of Scientific \& Technology Research, vol. 8, no. 9, pp. 324-327.

[36] Singer, E. and Couper, M. P. 2017“'Some Methodological Uses of Responses to Open Questions and Other Verbatim Comments in Quantitative Surveys," Methods, Data, Analyses, vol. 11, no. 2, pp. 115-134, https://doi.org/10.12758/mda.2017.01

[37] Siero, N. B. 2017 "Guidelines for Supporting Teachers in Teaching Digital Literacy," Retrieved from http://essay.utwente.nl/73163/

[38] Newland, B. and Handley, F. 2016 "Developing the digital literacies of academic staff: an institutional approach," Research in Learning Technology, vol. 24, pp. 1-16. https://doi.org/10.3402/rlt.v24.31501

[39] Svensson, M. and Baelo, R. 2015 "Teacher Students' Perceptions of their Digital Competence," Procedia - Social and Behavioral Sciences, vol. 180, pp. 1527-1534, https://doi.org/10.1016/j.sbspro.2015.02.302

[40] Reedy, K. and Goodfellow, R. 2012 "Digital and Information Literacy Framework," The Open Universit.

[41] Baharuddin, M. F., Masrek, M. N. and Mohamed Shuhidan, S. 2020 "Content Validity of Assessment Instrument for Innovative Work Behaviour of Malaysian School Teachers," International Journal of Scientific \& Technology Research, vol. 9, no. 4, pp. 1940-1946, Retrieved from http://www.ijstr.org/final-print/apr2020/ContentValidity-Of-Assessment-Instrument-For-Innovative-WorkBehaviour-Of-Malaysian-School-Teachers.pdf

[42] Cooper, D. R. 2016 "Business Research: A Guide to Planning, Conducting, and Reporting Your Study," SAGE Publications.

[43] Bowden, A., Fox-rushby, J. A., Nyandieka, L. and Wanjau, J. 2002 "Methods for pre-testing and piloting survey questions: illustrations from the KENQOL survey of health-related quality of life," Health Policy and Planning, vol. 17, no. 3, pp. 322-330.

[44] Sekaran, U. and Bougie, R. 2016 "Research methods for business: A Skill-Building Approach,".

[45] Polit, D. F. and Beck, C. T. 2006 "The Content Validity Index: Are You Sure You Know What's Being Reported? Critique and Recommendations," Research in Nursing \& Health, vol. 29, pp. 489-497, https://doi.org/10.1002/nur

[46] Lynn, M. R. 1986 "Determination and quantification of content validity," Nursing Research, vol. 35, pp. 382-385.

[47] Waltz, C. F. 1981 "Nursing Research: Design, statistics and computer analysis," Philadelphia. 